\title{
Parameter Psikometri Alat Ukur Strengths and Difficulties Questionnaire (SDQ)
}

\author{
Istiqomah \\ Universitas Muhammadiyah Malang, Jalan Raya Tlogomas 246 Kota Malang \\ e-mail: istiqomah@umm.ac.id
}

\begin{abstract}
$S D Q$ (Strengths and Difficulties Questionnaire) is a psychological scale to screen the Strengths and Difficulties the special student, emotional and behavioral problem, and school readiness. This adaptation of SDQ aims to test the psychometric parameter: validity, reliability and confirmatory factor analysis. The study was conducted to 153 subjects with the help of significant others in inclusive school and the center of autism at Malang. The analysis indicated 7 invalid items with reliability 0,759. The confirmatory factor analysis showed that all of factor give $54,943 \%$ contribution to the construct of SDQ.
\end{abstract}

Keywords: psychometric properties, Strengths and Difficulties Questionnaire (SDQ), students with special needs

\begin{abstract}
Abstrak
SDQ (Strengths and Difficulties Questionnaire) adalah skala psikologi yang digunakan untuk mengetahui kekuatan dan kelemahan siswa berkebutuhan khusus, permasalahan yang berhubungan dengan emosional dan perilaku pada anak-anak berkebutuhan khusus serta tingkat kesiapan belajar. Tujuan dari adaptasi skala $S D Q$ adalah untuk menguji parameter psikometri dari skala $S D Q$ yaitu validitas, reliabilitas dan confirmatory factor analysis. Subjek penelitian adalah siswa berkebutuhan khusus sebanyak 153 siswa dan yang mengisi alat ukur adalah significant others anak berkebutuhan khusus pada sekolah inklusi di Malang dan siswa pada Pusat Layanan Autis. Hasil penelitian menunjukkan bahwa dari 25 item terdapat 7 item yang tidak valid dengan mengacu pada r-tabel, adapun reliabilitas sebesar 0,759 . Analisis faktor alat ukur skala $S D Q$ bisa dikatakan berhasil karena bisa menjelaskan > 50\% pereduksian item sesuai faktor yaitu sebesar 54,943\% dari pembagian faktornya.
\end{abstract}

Kata Kunci: parameter psikometri, Strengths and Difficulties Questionnaire (SDQ), siswa berkebutuhan khusus

\section{Pendahuluan}

Anak berkebutuhan khusus (ABK) adalah anak dengan karakteristik khusus yang berbeda dengan anak pada umumnya tanpa menunjukkan pada ketidakmampuan mental, emosi dan fisik. Yang termasuk anak $\mathrm{ABK}$ adalah tuna netra, tuna rungu, tuna grahita, tuna daksa, tuna laras, kesulitan belajar, gangguan perilaku, anak berbakat, anak dengan gangguan kesehatan, dan anak autis. Mangunsong (2009) mendefinisikan anak berkebutuhan khusus sebagai anak yang menyimpang dari ratarata anak normal dalam hal ciri-ciri mental, kemampuan sensorik, fisik dan neuromuskular, perilaku emosional, kemampuan komunikasi maupun kombinasi dua atau lebih dari gejala di atas. Sejauh ini diperlukan modifikasi dari tugas-tugas sekolah, metode belajar atau pelayanan terkait lainnya, yang ditujukan untuk mengembangkan potensi dan kapasitas anak ABK. Anak berkebutuhan khusus memiliki beberapa permasalahan khususnya sikap prososial, hiperaktif, masalah emosi, tingkah laku terutama kemampuan bersosialisasi serta hubungan dengan teman sebaya.

Anak berkebutuhan khusus yang memiliki gangguan tuna netra, tuna rungu, tuna grahita, tuna daksa, atau tuna laras tidak dapat disekolahkan di sekolah umum. Mereka harus disekolahkan di sekolah 
khusus yaitu SLB dengan tipe A, B, atau C. Anak berkebutuhan khusus yang mampu disekolahkan pada sekolah reguler adalah anak autis, lambat belajar, dan gangguan perilaku. Pada anak-anak yang kondisinya sudah lebih baik diharapkan bisa disekolahkan di sekolah SD/ SMP reguler. Anak autis yang belum bisa disekolahkan biasanya harus tetap berada di pusat layanan autis atau melakukan terapi secara individual di rumah. Sekolah inklusi diharapkan juga menjadi terapi bagi anak autis untuk bersosialisasi dengan orang lain dan lingkungan.

Sekolah inklusi merupakan sebuah sistem pendidikan khusus yang mensyaratkan agar semua anak berkebutuhan khusus diterima di kelas reguler di sekolah yang berlokasi di daerah mereka dan mendapatkan berbagai pelayanan pendukung dan pendidikan berdasarkan pada kebutuhan mereka masing-masing (Praptiningrum, 2012). Pendidikan inklusif merupakan peluang bagi $\mathrm{ABK}$ untuk dapat menempuh pendidikan di sekolah reguler bersama anak-anak normal pada umumnya. ABK adalah mereka yang mengalami kondisi yang berbeda dari rata-rata anak normal pada umumnya baik dari segi fisik, kecerdasan, indera, komunikasi, perilaku atau gabungan dari hal-hal itu sehingga membutuhkan layanan khusus untuk dapat mengoptimalkan potensi yang ada dalam dirinya. ABK tersebut menerima dan mengikuti pelajaran serta berada di lingkungan yang sama dengan siswa reguler. Siswa berkebutuhan khusus tersebut menerima dan mengikuti pelajaran serta berada di lingkungan yang sama dengan siswa reguler.

Perkembangan akademik ABK dipengaruhi oleh IQ, faktor lingkungan serta kesiapan belajar secara emosional. Perlu adanya assessment untuk mengetahui kekuatan dan kelemahan anak autis sebelum masuk sekolah reguler (Keen, Webster dan Ridley, 2016)

Karakteristik spesifik anak berkebutuhan khusus pada umumnya berkaitan dengan tingkat perkembangan fungsional. Karakteristik tersebut berkaitan dengan tingkat perkembangan sensori-motor, kognitif, kemampuan berbahasa, keterampilan diri, konsep diri, kemampuan berinteraksi sosial serta kreativitasnya. Untuk mengetahui secara jelas tentang karakteristik setiap siswa, seorang guru terlebih dahulu melakukan screening atau assessment agar mengetahui secara jelas mengenai kompetensi diri peserta didik. Tujuannya adalah agar pada saat pemrograman pembelajaran, sudah dipikirkan mengenai bentuk intervensi pembelajaran yang cocok. Assesment disini adalah proses kegiatan untuk mengetahui kelemahan dan kelebihan setiap peserta didik dalam segi perkembangan kognitif dan perkembangan sosial. Kegiatan ini biasanya menggunakan instrumen khusus secara baku atau dibuat sendiri oleh guru kelas.

Menurut Salvia dan Ysldyke (dalam Delphie, 2005) assessment yang digunakan dalam pendidikan anak berkebutuhan khusus merupakan proses yang beraneka macam yang melibatkan lebih dari sekedar administrasi tes. Proses yang beraneka ragam melibatkan tiga aspek pokok, selain perilaku sasaran (target behavior) yakni: (1) Kondisi sebelumnya yang melatarbelakangi perilaku nonadaptif atau maladjustment disebut dengan antecedent conditions. (2) Karakteristik-karakteristik khusus dari siswa yang bersifat pribadi disebut dengan related personal characteristic. (3) Konsekuensi-konsekuensi yang akan diterima setelah dilakukannya progam pembelajaran individual disebut dengan consequent.

Didukung penelitian yang dilakukan oleh Ledford, Hall, Conder dan Lane, (2016) faktor lingkungan berhubungan erat dengan kesiapan belajar ABK sehingga bisa digunakan untuk memprediksi keberhasilan prestasi akademik anak berkebutuhan khusus di kemudian hari.

Keputusan untuk bisa dan siap dimasukkan di sekolah reguler merupakan tindakan yang harus diambil seorang 
psikolog untuk mempercepat kemampuan bersosialisasi. Kendala yang dihadapi adalah belum tersedianya alat khusus untuk mengetahui kekuatan dan kelemahan serta kesiapan belajar pada ABK. Kondisi ini akan menjadi hambatan tersendiri bagi sekolah untuk menentukan siswa yang akan diterima di sekolah tersebut sehingga alat ini sangat penting untuk diadaptasi karena kebutuhan yang mendesak untuk melakukan assessment kesiapan belajar siswa berkebutuhan khusus agar dapat sekolah di sekolah reguler.

Salah satu upaya untuk memenuhi kebutuhan tes kesiapan belajar bagi anak berkebutuhan khusus adalah dengan melakukan adaptasi terhadap alat ukur yang sudah ada yaitu strengths and difficulties questionnaire $(S D Q)$.

Dalam menggunakan tes yang diadaptasi dari luar negeri maka para psikolog terbentur pada budaya yang berbeda sehingga biasanya mereka akan melakukan adaptasi terlebih dahulu yaitu dengan cara menyesuaikan tes yang ada untuk dicocokkan dengan berbagai faktor yang dimiliki oleh populasi yang dikenai tes, salah satunya adalah budaya. Menurut Hambleton dan Patsula (1999), tindakan mengadaptasi atau menterjemahkan tes ke dalam bahasa/ budaya lain, pada umumnya disebabkan oleh alasan-alasan berikut: (1) Seringkali mengadaptasi lebih murah dan mudah daripada membuat tes yang baru dalam bahasa lokal. (2) Bila tujuan pengetesan adalah mengukur aspek psikologis masyarakat lintas budaya atau lintas negara, mengadaptasi tes adalah cara paling efektif untuk membuat tes dalam bahasa lokal. (3) Sedikitnya ahli-ahli dalam negara tersebut yang mampu membuat tes. (4) Terdapat rasa aman untuk digunakan pada tes yang sudah teradaptasi daripada tes yang baru dibuat, terutama bila tes yang diadaptasi adalah tes yang sudah terkenal. (5) Biasanya tetap muncul kesamaan atau kepercayaan yang sama terhadap hasil pengukuran, meskipun tes itu berbeda bahasanya.
Berdasarkan pemaparan di atas dapat diidentifikasi bahwa yang menimbulkan permasalahan dalam menggunakan alat ukur psikologi yang berasal dari luar negeri adalah adanya budaya yang berbeda yang mengakibatkan hasil tes yang merupakan sampel perilaku juga berbeda sehingga karakteristik tes yang didapatkan berupa validitas dan reliabilitas alat ukur akan berbeda pula. Berangkat dari pemikiran tersebut maka penulis perlu mengadaptasi alat ukur dalam bahasa Indonesia.

Tujuan penelitian ini adalah menguji validitas dan reliabilitas alat ukur SDQ. (2) Mendeskripsikan masalah emosional dan perilaku anak-anak berkebutuhan khusus. (3) Selain penelitian pada bidang psikometri, SDQ juga diteliti dalam kaitannya dengan masalah psikososial anak, yaitu untuk screening.

\section{Strengths and Difficulties Questionnaire $(S D Q)$}

SDQ adalah suatu alat ukur atau skala psikologi yang terdiri dari 25 item dengan lima dimensi yang akan diukur yaitu prososial, hiperaktif, masalah emosi, perilaku serta hubungan dengan teman sebaya. Tujuan daripada penyusunan skala SDQ yakni untuk mengetahui masalah yang berhubungan dengan emosional dan perilaku pada anak-anak dan remaja, dan mengetahui tingkat kesiapan belajar pada anak (Goodman, 1997). Pada SDQ Finlandia yang biasa disebut dengan SDQ Fin diperoleh reliabilitas sebesar 0.71.

Di Eropa studi tentang SDQ sudah banyak dilakukan terutama di Jerman (Becker dkk., 2004 dalam Goodman, 2006) telah menguji validitas dan reliabilitas SDQ pada 543 siswa dengan rentang usia 5-17 tahun. Becker menggunakan analisis faktor yaitu exploratory dan confirmatory factor analysis menemukan replikasi tepat dari SDQ ke lima skala asli.

Penelitian juga dilakukan di Amerika oleh Dickey dan Blumberg (2004) terhadap 9574 anak-anak dan remaja usia 4-17 tahun yang mengisi kuesioner SDQ. 
Analisis yang dilakukan adalah dengan menggunakan exploratory dan confirmatory factor analysis. Hasil penelitian menunjukkan bahwa dari kelima komponen yang diprediksi ada di dalam SDQ, hanya ada tiga faktor yang memenuhi confirmatory factor analysis.

Selain penelitian pada bidang psikometri, SDQ juga diteliti dalam kaitannya dengan masalah psikososial anak, perilaku dan emosional (Vostanis, 2006). Tujuan dari penelitian ini adalah untuk screening.

Aspek atau dimensi dalam skala SDQ antara lain: (1) Perilaku prososial merupakan sikap alamiah yang dimiliki oleh manusia disebabkan manusia tidak dapat hidup secara individualis dan termasuk makhluk sosial yang selalu membutuhkan orang lain dalam melakukan aktivitas sehari-hari. Baron dan Byrne (2005) mengatakan bahwa perilaku prososial adalah suatu tindakan menolong yang menguntungkan orang lain tanpa harus menyediakan suatu keuntungan langsung pada orang yang melakukan tindakan tersebut, dan mungkin bahkan melibatkan suatu risiko bagi orang yang menolong. (2) Hyperactivity. Aspek hyperactivity yaitu suatu pola perilaku pada seseorang yang menunjukkan sikap tidak mau diam, tidak menaruh perhatian, dan impulsif atau semaunya sendiri. Anak yang memiliki perilaku ini biasanya sulit diatur atau dikontrol. Perilaku yang tampak biasanya adalah: (a) Tidak dapat duduk dengan tenang, terlihat gelisah. (b) Sering meninggalkan bangku tanpa alasan yang jelas. (c) Berlari, memanjat tidak pada tempatnya, pada usia dewasa lebih ditunjukkan dengan sikap gelisah. (d) Kesulitan dalam menikmati kegiatan atau permainan yang tenang dan membawa relaksasi. (e) Berkeinginan untuk selalu bergerak aktif. (f) Cerewet, suka berbicara yang terkadang tidak sesuai dengan konteks. (3) Masalah perilaku (Conduct problem). Dari aspek perilaku mengganggu atau mengacau adalah suatu pola yang negatif, permusuhan dan perilaku menentang yang terus-menerus tanpa adanya pelanggaran serius terhadap norma sosial atau hak orang lain. Masalah perilaku ini merupakan permasalahan yang paling sering ditunjukkan oleh anak seperti memukul, berkelahi, mengejek, menolak untuk menuruti permintaan orang lain (4) Gejala emosi. Aspek gejala emosi mengarah pada suatu perasaan dalam pikiran yang khas, suatu keadaan biologis dan psikologis dalam serangkaian kecenderungan bertindak. Gangguan emosi merupakan ketidakmampuan yang ditandai oleh perasaan dan pikiran yang tidak sesuai dengan usia, budaya atau norma-norma etis yang berdampak buruk secara emosional dengan merespon perilaku dalam program-program pembelajaran sangat nyata pada akademis, sosial, keterampilan dan kepribadian (Kau, 2010). Anak dengan gangguan emosi dan perilaku memiliki karakteristik yang kompleks dan seringkali ciri-ciri perilakunya juga dilakukan oleh anak-anak sebaya lain, seperti banyak bergerak, mengganggu teman sepermainan, perilaku melawan, dan adakalanya perilaku menyendiri (5) $\mathrm{Hu}-$ bungan dengan teman sebaya. Masalah dengan teman sebaya ini dimana anak kurang bisa bersosialisasi dengan temanteman sebayanya baik di lingkungan rumah atau di sekolah. Kesulitan anak dalam bersosialisasi ini seringkali membuat anak kurang diterima oleh teman sebayanya, hal ini bisa membatasi anak untuk berinteraksi secara aktif dalam kelompok sebaya.

\section{Validitas}

Validitas adalah ketepatan tes dalam mengukur sesuatu yang harus diukur. Gronlund (1982) secara umum mengartikan validitas sebagai sejauhmana hasil tes dapat dipakai untuk tujuan yang dimaksudkan. Dengan perkataan lain validitas adalah kesesuaian tafsiran mengenai hasil tes.

Validitas tes terdiri dari validitas isi, validitas konstruk, dan validitas berdasarkan kriteria. Validitas berdasarkan kriteria terdiri atas validitas prediktif dan validitas 
konkuren (Azwar, 2013). Validitas isi tes menunjukkan sejauhmana seperangkat soal dilihat dari isinya memang mengukur apa yang dimaksudkan untuk diukur. Validitas konstruk mempersoalkan skor-skor hasil pengukuran dengan instrumen itu merefleksikan konstruksi teori tes yang mendasari penyusunan alat ukur tersebut. Validitas kriteria dilihat dari sejauhmana hasil pengukuran dengan alat ukur yang dipersoalkan itu sama atau mirip dengan hasil pengukuran lain yang dijadikan ukuran, dimana kriteria itu dapat dalam waktu sekarang atau waktu yang sesaat dan kriteria di waktu yang akan datang. Jika kriteria itu sekarang dapat dimanfaatkan disebut validitas konkuren, dan jika kriteria itu baru beberapa waktu kemudian dapat dimanfaatkan disebut validitas prediktif.

Validitas yang digunakan dalam adaptasi SDQ adalah validitas isi karena skala yang dikembangkan berdasarkan spesifikasi alat ukur atau isi dan validitas konstruk. Validitas isi mengacu pada sejauhmana butir-butir item itu mencakup keseluruhan isi yang hendak diukur. Hal ini berarti isi alat ukur tersebut harus tetap relevan dan tidak menyimpang dari tujuan pengukuran. Pengkajian validitas isi tidak melalui analisis statistik tetapi menggunakan analisis rasional atau penelaah. Cara yang ditempuh adalah melihat kesesuaian antara item skala yang asli dengan menggunakan bahasa Inggris dengan hasil alat ukur yang diadaptasi. Telaah butir item dilakukan oleh 2 orang penelaah yaitu dengan meminta bantuan dari lulusan sastra Inggris UM dan magister dari Universitas New Zealand yang dianggap expert karena mempunyai pengalaman dalam menerjemah soal bahasa Inggris ke dalam bahasa Indonesia dan sebaliknya. Prosedur pengujian validitas konstruk berangkat dari komputasi interkorelasi diantara berbagai hasil tes dan kemudian diikuti oleh analisis lebih lanjut terhadap matriks korelasi yang diperoleh, melalui berbagai metode. Metode yang digunakan dalam pengujian validitas konstruk adalah korelasi item dengan total dan analisis faktor.

\section{Analisis Faktor}

Analisis faktor adalah prosedur untuk mengidentifikasi item atau variabel berdasarkan kemiripannya. Kemiripan tersebut ditunjukkan dengan korelasi yang tinggi. Item-item yang memiliki korelasi yang tinggi akan membentuk satu kerumunan faktor (Widiarso, 2009).

Analisis faktor memungkinkan peneliti untuk: 1) menguji ketepatan model (goodness of fit tes) faktor yang terbentuk dari item-item alat ukur, 2) menguji kesetaraan unit pengukuran antar item, 3) menguji reliabilitas item-item pada tiap faktor yang diukur, 4) menguji adanya invariant item pada populasi. Analisis faktor terdiri dari exploratory factor analysis yaitu suatu analisis yang digunakan untuk mengetahui atau mengidentifikasi faktor yang ada di dalam seperangkat item tersebut dan confirmatory factor analysis yaitu analisis faktor yang digunakan untuk menguji suatu alat ukur yang telah diketahui dimensinya. Jadi untuk membuktikan bahwa alat ukur tersebut memang terbukti terdiri dari beberapa faktor.

\section{Reliabilitas}

Reliabilitas adalah keterandalan, konsistensi bisa juga dikatakan sebagai sejauhmana hasil suatu pengukuran dapat dipercaya (Azwar, 2013). Menurut Nunnaly (1994) koefisien reliabilitas 0,7 sampai 0,8 dianggap cukup baik. Reliabilitas yang diperoleh alat ukur SDQ Finlandia (SDQ Fin) diperoleh reliabilitas sebesar 0.71 (Goodman, 1997).

Uji reliabilitas skala ini menggunakan metode konsistensi internal, salah satu prosedur dalam metode konsistensi internal yang digunakan adalah teknik Cronbach's Alpha. Teknik tersebut dapat digunakan untuk menguji skala, angket maupun tes dengan tingkat kesukaran seimbang atau hampir seimbang. 


\section{Adaptasi tes}

Adaptasi tes adalah penyesuaian materi tes karena adanya perbedaan budaya atau pada budaya yang sama dengan karakteristik test taker yang berbeda-beda dengan tidak mengubah fungsi tes tersebut. Adaptasi tes meliputi cultural adaptation dan test taker.

Menurut Hambleton, Mirenda dan Spielberg (2005) dalam adaptasi tes yang perlu diperhatikan adalah bahasa dan budaya. Skala yang diadaptasi harus diterjemahkan terlebih dahulu ke dalam bahasa tersebut (bahasa Indonesia), baru kemudian diterjemahkan ulang ke dalam bahasa aslinya. Faktor budaya juga harus diperhatikan karena budaya tertentu yang disampaikan dengan bahasa yang berbeda maka akan memberikan makna yang berbeda pula.

Langkah-langkah adaptasi tes (Soekarti, 2003). (1) Memahami karakteristik tes yang meliputi: landasan teoretis, definisi operasional, standar administrasi, standar format tes dibuat dengan bentuk-bentuk tertentu yang memiliki makna dan tujuan, karakteristik test taker yang meliputi usia dan pendidikan. (2) Menerjemah atau menyadur alat ukur tersebut yang meliputi: perbedaan konstruk bahasa atau idiom, memperhatikan istilah-istilah lokal, dan rasionalisasi setiap item yang tujuannya untuk melihat makna dan aspek yang diukur tidak menyimpang dari aslinya. Tes diterjemahkan ke dalam bahasa Indonesia, kemudian dikembalikan ke dalam bahasa aslinya. Dalam menerjemahkan bahasa bisa dilakukan dengan menerjemahkan tes yang jawabannya pasti tetapi bisa juga mengubah item tersebut sesuai dengan kondisi, kebiasaan hidup, agama, norma sosial dan sebagainya. (3) Menelaah item. Telaah merupakan suatu proses penting yang harus dilakukan dalam adaptasi skala. Penelaahan butir item dilakukan untuk menentukan apakah item tersebut sudah dianggap baik dan memenuhi kriteria penilaian kualitatif sebelum diujicobakan.
Penelaahan butir soal dilakukan oleh 2 orang yang ahli dalam bidang bahasa dan pengukuran. (4) Data psikometrik yang berupa penghitungan-penghitungan statistik yang merupakan data psikometrik mengenai tes tersebut yaitu validitas dan reliabilitas.

\section{Metode Penelitian}

\section{Partisipan}

Partisipan penelitian adalah sumber utama data penelitian, yaitu yang memiliki data mengenai yang diteliti (Azwar, 2013). Subjek penelitian yang akan digunakan adalah significant others siswa ABK (autis) SD atau SMP pada sekolah inklusi di Malang.

Teknik sampling yang digunakan adalah purposive random sampling yaitu teknik penentuan sampel dengan memenuhi karakteristik tertentu. Karakteristik yang harus dipenuhi adalah siswa berkebutuhan khusus yang telah memenuhi usia sekolah SD. Adapun yang mengisi skala adalah significant others yang mana dapat diisi oleh orang tua ataupun guru yang mengetahui perkembangan siswa selama 6 bulan terakhir.

Sebagai suatu rekomendasi umum, Crocker dan Algina (1986), menyarankan jumlah 200 orang sebagai jumlah sampel yang cukup memadai. Gable (dalam Azwar, 2013) mengatakan bahwa banyaknya responden guna memperoleh data uji coba ini kira-kira 6 sampai 10 kali lipat banyaknya item yang hendak dianalisis. Sedangkan Nunnaly (1994) memberikan pedoman kasar, yaitu banyaknya subjek untuk sampel adalah 5 sampai 10 kali lipat banyaknya item yang hendak dianalisis.

Pada penelitian ini patokan jumlah responden yang digunakan adalah menurut Gable yaitu 6 sampai 10 kali lipat banyaknya item. Jumlah item skala ini adalah 25 item, jadi subjek penelitian ini adalah antara 150-250 siswa yaitu 153 dan sudah memenuhi kriteria untuk melakukan uji coba alat ukur. 


\section{Instrumen Penelitian}

Alat ukur yang digunakan adalah SDQ Fin yang dikembangkan oleh Goodman (2006) yang terdiri dari 25 item yang didasarkan pada lima dimensi. Alat ukur ini telah diuji validitas dan reliabilitasnya. Uji reliabilitas yang telah dilakukan diperoleh sebesar 0,71. Alasan menggunakan alat ukur ini adalah di Indonesia belum ada dan alat ukur ini sangat dibutuhkan untuk mengetahui kesiapan belajar anak ABK.

\section{Prosedur Penelitian dan Analisis Data Penelitian}

Penelitian ini dilakukan dalam tiga tahap, yang terdiri dari tahap persiapan, tahap adaptasi alat ukur, dan tahap analisa data. (a) Tahap persiapan. Persiapan penelitian dimulai dengan mencari informasi bahwa tes yang akan diadaptasi sudah mempunyai bukti-bukti merupakan tes yang baik dan bisa digunakan. (b) Tahap adaptasi skala. Adaptasi tes adalah penyesuaian materi tes karena adanya perbedaan budaya atau pada budaya yang sama dengan test taker tanpa mengubah fungsi tes tersebut. Adaptasi tes meliputi cultural adaptation dan test taker. Langkah-langkah adaptasi tes

Memahami karakteristik tes yang meliputi: landasan teoretis, definisi operasional, standar administrasi, standar format tes dibuat dengan bentuk-bentuk tertentu yang memiliki makna dan tujuan. Karakteristik test taker yang meliputi usia dan pendidikan. (2) Menerjemah atau menyadur alat ukur SDQ yang meliputi: perbedaan konstruk bahasa atau idiom, memperhatikan istilah-istilah lokal, dan rasionalisasi setiap item yang tujuannya untuk melihat makna dan aspek yang diukur tidak menyimpang dari aslinya. Tes diterjemahkan ke dalam bahasa Indonesia, kemudian dikembalikan ke dalam bahasa aslinya (bahasa Inggris). Dalam menerjemahkan bahasa bisa dilakukan dengan tes yang jawabannya pasti tetapi bisa juga mengubah item tersebut sesuai dengan kondisi, kebiasaan hidup, agama, norma sosial dan sebagainya. (3) Menelaah item. Telaah merupakan suatu proses penting yang harus dilakukan dalam adaptasi skala. Penelaahan butir item dilakukan untuk menentukan apakah item sudah dianggap baik dan memenuhi kriteria penilaian kualitatif sebelum diujicobakan. Penelaahan butir soal dilakukan oleh 2 orang yang ahli dalam bidang bahasa dan pengukuran. (4) penghitungan-penghitungan statistik sebagai data psikometri mengenai tes tersebut yaitu validitas dan reliablitas (Soekarti, 2003).

\section{Uji Coba}

Uji coba tes dilaksanakan mungkin cukup sekali atau lebih sampai mendapatkan butir soal yang memenuhi kriteria. Suryabrata (2000) menyatakan jika satu kali uji coba sudah mendapatkan tes yang memadai maka uji coba cukup dilakukan satu kali. Penelitian dilakukan dengan memberikan alat ukur kepada responden untuk diisi secara lengkap dan pada penelitian ini yang mengisi skala adalah significant others ABK.

\section{Kelemahan dalam Adaptasi Tes}

Dalam adaptasi tes ini masih memiliki beberapa kelemahan yaitu adaptasi tes ini merupakan studi pendahuluan dalam menguji validitas dan reliabilitas alat ukur, maka pada pengujian validitas dan reliabilitas skala ini hanya sampai pada pengujian setelah disadur atau diterjemahkan saja. Belum ada pengubahan atau revisi pada item-itemnya sehingga jika skala ini akan digunakan maka pada item yang diterima dengan revisi harus direvisi terlebih dahulu dan item yang harus diganti harus diganti terlebih dahulu kemudian diujicobakan lagi, dianalisis ulang baru kemudian diinterpretasikan apakah bisa langsung digunakan atau harus revisi ulang. Dalam uji coba alat ukur dengan metode adaptasi ini tidak dapat dilakukan hanya sekali uji coba melainkan berulang kali sampai ditemukannya suatu skala baku yang memenuhi karakteristik item. Pada 
tahap ini hanya dilakukan uji validitas dan reliabilitas, sedangkan revisi dan uji coba berikutnya dilakukan pada penelitian yang akan datang.

\section{Tahap analisis data}

Analisis data meliputi analisis butir soal dan reliabilitas alat ukur. Analisis item secara kuantitatif dilakukan dengan menggunakan software statistik. Dari print out program tersebut dilakukan analisis lebih lanjut untuk melihat karakteristik item yang memenuhi kriteria. Analisis butir soal bertujuan untuk mendapatkan bukti-bukti empiris mengenai daya beda dan reliabilitas alat ukur.

Reliabilitas yang digunakan adalah Cronbach Alpha. Koefisien Alpha diperoleh melalui penyajian satu bentuk skala yang dikenakan hanya sekali saja pada sekelompok responden (single trial administration). Koefisien reliabilitas berdasarkan kesepakatan informal adalah > 0,70 (Nunnaly, 1994).

\section{Hasil Penelitian dan Pembahasan}

\section{Deskripsi Data}

Data yang diperoleh di lapangan dari beberapa sekolah inklusi di Malang dapat dipaparkan pada tabel 1.

\section{Pembahasan Hasil Try Out}

Uji validitas dan reliabilitas skala The Strengths and Difficulties Questionnaire secara keseluruhan menunjukkan bahwa dari 25 item terdapat 7 item yang gugur yaitu $(4,6,7,15,17,21,25)$. Dari item yang valid semua telah memenuhi seluruh kawasan domain ukur sehingga alat ukur ini bisa digunakan untuk mengukur kekuatan dan kelemahan siswa berkebutuhan khusus, permasalahan yang berhubungan dengan emosional dan perilaku pada anak-anak berkebutuhan khusus serta tingkat kesiapan belajar. Dari 5 item yang tidak valid, hasil ini menunjukkan bahwa pada masing-masing item nomor $(6,7,15,17,21)$ masih bisa dikategorikan baik tetapi jika mau digunakan maka harus direvisi terlebih dahulu karena sebenarnya item ini masih bisa dipertahankan. Item ini memiliki korelasi item di bawah harga r-tabel. Pada item $(4,25)$ tidak dapat digunakan karena korelasi item dengan total negatif. Jika menginginkan digunakan sesuai dengan jumlah item skala yang asli harus membuat item baru dan harus diujicobakan ulang. Reliabilitas yang diperoleh adalah 0,759 hasil ini sesuai dengan SDQ Fin 0,71 artinya reliabilitas yang diperoleh mendekati skala aslinya. Reliabilitas alat ukur sebesar $\mathrm{r}_{\mathrm{xx}}=0,759$ termasuk kategori baik karena reliabilitas alat ukur semakin mendekati 1 semakin baik. Pada masingmasing faktor didapat-kan reliabilitas sebesar: faktor $1 r_{x x}=0,852$; faktor 2 $r_{x x}=0,753$; pada faktor $3 r_{x x}=0,804$; faktor 4 $r_{x x}=0,486$; faktor $5 r_{x x}=0,513$. Reliabilitas yang didapatkan pada faktor 4 dan 5 tidak terlalu tinggi.

Reliabilitas pada skala asli SDQ Fin pada masing-masing faktor didapatkan reliabilitas sebesar: faktor $1 r_{x x}=0,86$; faktor $2 r_{x x}=0,85$; faktor $3 r_{x x}=0,79$; faktor $4 r_{x x}=0,72$; faktor $5 r_{x x}=0,73$. Reliabilitas yang didapatkan pada faktor 4 dan 5 tidak menunjukkan adanya konsistensi karena terkait jumlah item yang valid tidak terlalu banyak. Hasil ini menunjukkan bahwa reliabilitas perfaktor yang diperoleh pada skala asli dan skala yang sudah diadaptasi tidak jauh berbeda pada faktor 1, faktor 2, faktor 3, sedangkan faktor 4 dan faktor 5 terdapat perbedaan reliabilitas. 
Tabel 1

Deskripsi Data Subjek

\begin{tabular}{|c|c|c|c|}
\hline No & Jenis Gangguan & Jumlah & Persentase \\
\hline 1 & Autis & 53 & $35,6 \%$ \\
\hline 2 & Gangguan ABK lainnya & 100 & $65,4 \%$ \\
\hline
\end{tabular}

Tabel 2

Jumlah Item Valid secara Keseluruhan

\begin{tabular}{ccccc}
\hline $\begin{array}{c}\text { Jumlah Item } \\
\text { Semula }\end{array}$ & $\begin{array}{c}\text { Jumlah Item yang } \\
\text { Valid }\end{array}$ & Jumlah Item Gugur & Indek Validitas & Reliabilitas \\
\hline 25 & 18 & $7(4,6,7,15,17,21,25)$ & $0,132-0,624$ & 0,759 \\
\hline
\end{tabular}

Tabel 3

Jumlah Item Valid Perdimensi

\begin{tabular}{clcccc}
\hline No & \multicolumn{1}{c}{ Dimensi } & Item & Item yang Gugur & Indeks Validitas & Reliabilitas \\
\hline 1 & Prosocial & $1,4,9,17,20$ & - & $0,665-0,738$ & 0,852 \\
2 & Hyperactivity & $2,10,15,21,25$ & 21,25 & $0,172-0,413$ & 0,753 \\
3 & Emotional & $3,8,13,16,24$ & - & $0,346-0,771$ & 0,804 \\
4 & Conduct Problem & $5,7,12,18,22$ & - & $0,223-0,323$ & 0,486 \\
5 & Peer problem & $6,11,14,19,23$ & 6,11 & $0,277-0,314$ & 0,513 \\
\hline
\end{tabular}

Tabel 4

Hasil Pereduksian Faktor

Total Variance Explained

\begin{tabular}{ccccccc}
\hline \multirow{2}{*}{ Component } & \multicolumn{3}{c}{ Initial Eigenvalues } & \multicolumn{2}{c}{ Extraction Sums of Squared Loadings } \\
\cline { 2 - 6 } & Total & \% of Variance & Cumulative \% & Total & \% of Variance & Cumulative \% \\
\hline 1 & 5,629 & 22,517 & 22,517 & 5,629 & 22,517 & 22,517 \\
2 & 3,339 & 13,356 & 35,873 & 3,339 & 13,356 & 35,873 \\
3 & 1,717 & 6,870 & 42,743 & 1,717 & 6,870 & 42,743 \\
4 & 1,628 & 6,512 & 49,255 & 1,628 & 6,512 & 5,255 \\
5 & 1,422 & 5,689 & 54,943 & 1,422 & & \\
6 & 1,133 & 4,532 & 59,475 & & \\
7 & 1,078 & 4,313 & 63,788 & & \\
8 &, 984 & 3,938 & 67,726 & & \\
9 &, 878 & 3,511 & 71,237 & & \\
10 &, 847 & 3,387 & 74,625 & & \\
11 &, 807 & 3,227 & 77,852 & & \\
12 &, 680 & 2,719 & 80,571 & & \\
13 &, 606 & 2,423 & 82,993 & & \\
14 &, 562 & 2,248 & 85,241 & & \\
15 &, 541 & 2,164 & 87,405 & & \\
16 &, 459 & 1,838 & 89,243 & & \\
17 &, 416 & 1,663 & 90,906 & & \\
18 &, 367 & 1,468 & 92,374 & & \\
19 &, 343 & 1,372 & 93,746 & & \\
20 &, 331 & 1,323 & 95,069 & & \\
21 &, 321 & 1,283 & 96,353 & & \\
22 &, 294 & 1,176 & 97,529 & & \\
23 &, 244 &, 976 & 98,505 & & \\
24 &, 208 &, 831 & 99,336 & & \\
25 &, 166 &, 664 & 100,000 & & \\
\hline
\end{tabular}


Tabel 5

Kategori Skala The Strengths and Difficulties Questionnaire pada Masing-masing Dimensi

\begin{tabular}{ccc}
\hline No & Skor & Kategori \\
\hline 1 & $0-17$ & Rendah \\
2 & $18-34$ & Sedang \\
3 & $35-50$ & Tinggi \\
\hline
\end{tabular}

Kategori ini dihitung berdasarkan skor tertinggi dan skor terrendah kemudian dibagi dengan jumlah kategori.

Tabel 6

Hasil Masing-masing Dimensi

\begin{tabular}{clc}
\hline No & \multicolumn{1}{c}{ Dimensi } & Kategori \\
\hline 1 & Prosocial & Sedang \\
2 & Hyperactivity & Tinggi \\
3 & Emotional & Sedang \\
4 & Conduct problem & Sedang \\
5 & Peer problem & Sedang \\
\hline
\end{tabular}

Hasil analisis faktor menunjukkan bahwa pada faktor 1 dengan $r_{x x}=0,852$ semua item sesuai dengan item yang direncanakan. Pada faktor ke-2 dengan $\mathrm{r}_{\mathrm{xx}}=$ 0,753 tidak ada item yang sesuai dengan analisis faktor, item $(2,10,15)$ masuk pada faktor ke-3, sedangkan item $(21,25)$ masuk pada faktor ke-4. Pada faktor ke-3 dengan $\mathrm{r}_{\mathrm{xx}}=0,804$ tidak ada item yang sesuai dengan analisis faktor, semua item masuk pada faktor ke-2. Pada faktor ke-4 dengan $\mathrm{r}_{\mathrm{xx}}=0,486$ tidak ada item yang sesuai dengan analisis faktor, item $(5,7,12)$ masuk pada faktor ke-5, sedangkan item (18) masuk pada faktor ke-2 dan item (22) masuk pada faktor ke-2. Pada faktor ke-5 dengan $r_{x x}=0,513$ tidak ada item yang sesuai dengan analisis faktor, item $(6,23)$ masuk pada faktor ke-2, sedangkan item $(11,19)$ masuk pada faktor ke-3 dan item (14) masuk faktor ke-4.

Total variance explained adalah persen-tase varians konstruk ukur yang dapat dijelaskan oleh pembagian faktor. Hallahan dan Frucher (1954) menyatakan bahwa jika hasil dari pereduksian item sesuai dengan faktornya serta dapat menjelaskan $50 \%$ dari varians maka dapat dikatakan berhasil. Dalam adaptasi alat ukur skala The Strengths and Difficulties
Questionnaire bisa dikatakan berhasil karena bisa menjelaskan $>50 \%$ pereduksian item sesuai faktor yaitu sebesar $54,943 \%$ dari pembagian faktornya.

\section{Diskusi}

Pada dasarnya skala The Strengths and Difficulties Questionnaire ini sudah dapat digunakan meskipun terdapat beberapa item yang tidak valid tetapi dari total item yang valid masih mengukur seluruh kawasan domain ukur artinya dari masingmasing aspek masih terwakili itemnya.

Berdasarkan pengukuran kesiapan belajar siswa diketahui bahwa tingkat prososial siswa masuk kategori sedang, tingkat hiperactivity yang tinggi, emotional sedang, conduct problem sedang dan peer problem sedang. Hasil ini menunjukkan bahwa perlu adanya intervensi khusus untuk meningkatkan prososial siswa ABK.

Penelitian yang dilakukan oleh Solantaus, Paavonen, Toikka, dan Punamäki (2010) menunjukkan intervensi dengan menggunakan psikoedukasi dapat menurunkan dan mengurangi gejala emosional, kecemasan, dan sedikit hiperaktivitas anak sehingga didapatkan cara untuk meningkatkan perilaku prososial pada anak. Dengan melakukan diskusi psikoedukasi dengan orang tua anak untuk mendukung efektivitas intervensi pada anak.

Pada penelitian sebelumnya oleh Barr dan Higgins-D'Alessandro (2007) empati dan perilaku prososial remaja dalam konteks multidimensional budaya sekolah menjelaskan adanya hubungan antara empati dengan perilaku prososial yang dipengaruhi gender. Siswa laki-laki yang memiliki persepsi positif yang lebih tinggi akan memiliki empati yang tinggi pula tetapi kurang dalam perilaku prososial.

Tidak dapat dipungkiri juga bahwa dalam pengembangan alat ukur akan muncul hambatan dalam pelaksanaannya. Adanya item-item yang ternyata tidak sesuai faktor-faktornya bahkan item tersebut berada dalam satu faktor hal ini menunjukkan bahwa kemampuan dalam 
memahami konstruk yang hendak kita buat alat ukurnya harus benar-benar dikuasai. Perlu adanya pembatasan dalam mengkonseptualisasi setiap faktornya.

\section{Simpulan dan Saran}

\section{Simpulan}

Berdasarkan hasil analisis dan interpretasi data dapat dikemukakan simpulan penelitian sebagai berikut: (1) hasil uji validitas dan reliabilitas skala The Strengths and Difficulties Questionnaire secara keseluruhan diperoleh bahwa dari 25 item terdapat 7 item yang gugur yaitu $(4,6,7,15,17,21,25)$ dan item yang valid masih mencakup seluruh kawasan domain ukur. (2) Item no $(6,7,15,17,21)$ masih bisa dikategorikan baik tetapi jika akan digunakan maka harus direvisi terlebih dahulu karena sebenarnya item ini masih bisa dipertahankan. Item ini memiliki korelasi item dengan total $>0,200$ dan di bawah harga r-tabel artinya adalah berdasarkan penghitungan harga $r$ berdasarkan r-hitung sehingga ditemukan batas suatu item dikatakan valid. (3) Pada item $(4,25)$ tidak dapat digunakan karena berkorelasi negatif. (4) Hasil analisis faktor menunjukkan bahwa hanya 4 item yang sesuai dengan faktor yang direncanakan, adapun selebihnya masuk pada faktor lain. (5) Pereduksian 18 item menjadi 1 faktor dapat menjelaskan $22,517 \%$ varians, pembagian 2 faktor menjelaskan 35,873\% sedangkan pembagian menjadi 3 faktor dapat menjelaskan $42,743 \%$ varians. Pembagian menjadi 4 faktor dapat menjelaskan 49,255\% varians dan pembagian menjadi 5 faktor dapat menjelaskan 54,943\% varians. Berdasarkan data tersebut hasil analisis faktor ini bisa dikatakan berhasil karena hasil pereduksian dari 18 item menjadi 5 faktor hasilnya $>50 \%$ pereduksian item sesuai faktor yaitu sebesar 54,943\% dari pembagian faktornya. (6) Tingkat prososial siswa ABK termasuk kategori sedang, hyperactivity tinggi, emotional sedang, conduct problem sedang dan peer problem sedang.
Kesulitan utama dalam adaptasi tes ini adalah pencarian sampel yang representatif yaitu memenuhi jumlah sebesar (item x 610). Jumlah ideal adalah 150-250 subjek penelitian. Harapan peneliti adalah jumlah maksimal yaitu 250 subjek penelitian, tetapi hanya terpenuhi sekitar 153 subjek penelitian (jumlah item x 6) karena subjek penelitian ini hanya pada ABK yang mana jumlah ABK tidak terlalu banyak, dan ini sudah memenuhi persyaratan untuk uji coba suatu alat ukur.

\section{Saran}

Berdasarkan hasil penelitian dapat dikemukakan saran-saran sebagai berikut: (1) Skala ini bisa digunakan dengan catatan 5 item yang tidak valid direvisi terlebih dahulu dan 2 item harus diganti, diujicobakan kembali dan dianalisis ulang sehingga mendapat item yang keseluruhannya valid. (2) Perlu dilakukan studi lanjut untuk mengukur validitas dan reliabilitas alat ukur khususnya pada item yang harus direvisi maupun yang diganti dan dilanjutkan pengujian analisis faktor untuk menganalisis faktor-faktor yang diungkap dalam skala tersebut. (3) Berdasarkan koreksi pada 7 item yang harus direvisi, item tersebut harus direvisi sesuai dengan faktor yang hendak diukur khususnya pada faktor hyperactivity, gejala emosional, masalah perilaku dan teman sebaya alasannya adalah pada item tersebut tidak sesuai dengan faktornya.

\section{Daftar Pustaka}

Azwar, S. (2013). Reliabilitas dan Validitas Edisi II, Yogyakarta: Pustaka Pelajar

$$
\text { (2013). Sikap Manusia }
$$

Teori dan Pengukurannya, Yogyakarta: Pustaka Pelajar.

Baron, R.A. \& Byrne, D. (2005). Psikologi Sosial, Jakarta: Erlangga.

Barr, J.J. \& Higgins-D'Alessandro, A. (2007). Adolescent Empathy and Prosocial Behavior in the Multidimensional Context of School 
Culture, The Journal of Genetic Psychology, 168(3), 231-250.

Crocker, L. \& Algina, J. (1986). Introduction To Classical and Modern Test Theory, Second Edition, Holt Renehart and Wiansion.

Delphie, B. (2005). Bimbingan Perilaku Adaptif, Malang: Elang Mas.

Dickey, W.C. \& Blumberg, S.J. (2004). Revisiting the from PSY 6095 at Capella University, Psychological Bulletin, 131483509.

Frucher, B. (1954). Introduction to Factor Analysis, New York: D. Van Nostrand Company.

Goodman, R. (1997) The Strengths and Difficulties Questionnaire: A Research Note, Journal of Child Psychology and Psychiatry, 38, 581586.

(2006) Evaluation of the Strengths and Difficulties Questionnaire. Aboriginal Children's Survey.

Gronlund, N.E. (1982). Constructing Achievement Tests, Publisher Englewood Cliffs: Prentice-Hall.

Hallahan, D.P. \& Frucher, B. (1954). Introduction to Factor Analysis, New York: D. Van Nostrand Company.

Hambleton, R.K., Mirenda, D.F., \& Spielberg, C. (2005). Adapting Educational and Psychological Test for Cross Culture, New Jersey: Lawrence Erlbaum Associates Publishers.

Hambleton, R.K. \& Patsula, L. (1999). Increasing the Validity of Adapted Test: Myth to be Avoided and Guidelines for Improving Test Adaptation Practices, Journal of Applied Testing Psychology, August 1999, Association of Test Publishers (ATP).

Kau, M.A. (2010). Empati dan Perilaku Prososial Pada Anak, Jurnal Inovasi, 7(03).

Kauffman, J.M. (2006). Exceptional Learner: An Introduction to Special
Education (International Edition: $10^{\text {th }} \mathrm{ed}$ ), Boston: Allyn and Bacon.

Keen, D., Webster, A., \& Ridley, G. (2016). How Well are Children with Autism Spectrum Disorder Doing Academically at School? An Overview of the Literature, http://doi.org/10.1177/1362361315580 962

Ledford, J.R., Hall, E., Conder, E., \& Lane, J.D. (2016). Research for Young Children with Autism Spectrum Disorders: Evidence of Social and Ecological Validity, http://doi.org/10.1177/0271121415585 956

Lestari. (2013). Metode Guru BK dalam Mengatasi Problem Penyesuaian Diri pada Anak Berkebutuhan Khusus (Studi Kasus pada Siswa Tunarungu di SLB Purworaharjo).

Mangunsong, F. (2009). Psikologi dan Pendidikan Anak Berkebutuhan Khusus Jilid 1, Jakarta: Lembaga Pengembangan Sarana Pengukuran dan Pendidikan Psikologi (LPSP3) Fakultas Psikologi Universitas Indonesia.

Nunnaly, J.C. (1994). Psychometric Theory, New York: McGraw Hill.Inc.

Praptiningrum, N. (2012). Fenomena Penyelenggaraan Pendidikan Inklusif bagi Anak Berkebutuhan Khusus, Jurnal Pendidikan Khusus, 7(2).

Soekarti, 2003. Diktat Kuliah Sistem Pengelolaan Tes, Yogyakarta: Tidak Diterbitkan.

Solantaus, T., Paavonen, E.J., Toikka, S., \& Punamäki, R.L. (2010). Preventive Interventions in Families with Parental Depression: children's Psychosocial Symptoms and Prosocial Behaviour, European Child \& Adolescent Psychiatry, 19(12), 883-892.

Suryabrata, S. (2000). Penyusunan Alat Ukur Psikologi, Yogyakarta: Pustaka Pelajar. 
Vostanis, P. (2006). Strengths and Difficulties Questionnaire: Research and Clinical Applications, Current Opinion in Psychiatry, 19, 367-372.
Widiarso, W. (2009). Modul Statistik, Yogyakarta: Tidak Diterbitkan. 
Psympathic, Jurnal Ilmiah Psikologi Desember 2017, Vol. 4, No. 2, Hal : 251 - 264 